\title{
Typhlodromus pyri and Euseius finlandicus (Acari: Phytoseiidae) as potential biocontrol agents against spider mites (Acari: Tetranychidae) inhabiting willows: laboratory studies on predator development and reproduction on four diets
}

\author{
Ewa K. Puchalska' ${ }^{1}$ Marcin Kozak ${ }^{2}$
}

Received: 13 May 2015/Accepted: 6 October 2015/Published online: 3 November 2015

(C) The Author(s) 2015. This article is published with open access at Springerlink.com

\begin{abstract}
Typhlodromus pyri Scheuten and Euseius finlandicus (Oudemans) are important predators of phytophagous mites. The present laboratory study aimed to determine whether both species can develop and reach maturity feeding on spider mites occurring on willows, i.e., Schizotetranychus schizopus (Zacher), Schizotetranychus garmani Pritchard \& Baker, and Tetranychus urticae Koch, and on Brassica napus L. pollen. The predators' development, reproduction and demographic parameters were significantly affected by diet. The data suggest that rape pollen can be useful in mass rearing of E. finlandicus but is completely unsuitable as alternative food for $T$. pyri. Short development time and high values of population parameters achieved by $T$. pyri feeding on larvae and protonymphs of $S$. schizopus and by E. finlandicus feeding on juvenile stages of $S$. garmani indicate great suitability of these preys as food for the phytoseiids, and make both predatory species promising biocontrol agents in spider mite control on willows.
\end{abstract}

Keywords Life table - Biological control - Alternative food - Development · Predator . Pollen

Ewa K. Puchalska

ewa_puchalska@sggw.pl

Marcin Kozak

nyggus@gmail.com

1 Department of Applied Entomology, Faculty of Horticulture, Biotechnology and Landscape Architecture, Warsaw University of Life Sciences-SGGW, Warsaw, Poland

2 Department of Botany, Faculty of Agriculture and Biology, Warsaw University of Life SciencesSGGW, Warsaw, Poland 


\section{Introduction}

Plants of the genus Salix are grown for energy purposes (Gigler et al. 1999; Johansson and Lundqvist 1999) and for the chemical industry (cellulose, bio-alcohols; Cook and Beyea 2000) and furniture industry (Sean and Labrecque 2006; Warmbier et al. 2010). Willows also have a high ecological value; for example, they are used to form protection zones along the routes (motorways) against noise or emissions of pollutants, and for reclamation of areas degraded and destroyed by industrial activities (Waliszewska et al. 2011). Several species and cultivars of willow are grown in ornamental nurseries and offered as a decorative element of landscape architecture.

Among many phytophagous arthropods occurring on cultivated willows, spider mites (Tetranychidae), i.e., Schizotetranychus schizopus (Zacher), Schizotetranychus garmani Pritchard \& Baker and Tetranychus urticae Koch, are considered key pests (Soika and Łabanowski 2003; Tomczyk 2004; Puchalska et al. 2014). Difficulties of these pests' management result from the rapid development of resistance to many acaricides used for their control. High fecundity, inbreeding, very short life-cycle, and high mutation rate of tetranychids facilitate resistance development and often induce a high degree of crossresistance to pesticides (Cranham and Helle 1985; Van Leeuwen et al. 2009). Therefore, it seems reasonable to seek alternatives to chemical control of spider mites, including those occurring on willows. One of the possibilities is using biological agents.

The most important natural enemies of tetranychids are phytoseiid mites (McMurtry and Croft 1997). Nevertheless, biological control of spider mites with the use of phytoseiids is mainly based on introducing exotic species into greenhouses (Naher and Haque 2007; Oliveira et al. 2009). So far, only few attempts have been made to introduce predatory mites on ornamental plants in outdoor cultivation (Pratt et al. 2002; Shrewsbury and Hardin 2003; Kaźmierczak 2004). Releasing exotic natural enemies, especially in open-field cropping systems, may fail, e.g., due to lack of environmental adaptation or insufficient synchronization of life cycles of the agent and target pest (Gurr and Wratten 2000). In such a case releasing indigenous species of predators gives better results in pest control and also reduces potential risk of negative effects on non-target species and ecosystem in which the species function (Lockwood et al. 2001; van Lenteren et al. 2003; Wajnberg et al. 2007).

Observations of the Phytoseiidae complex occurring on willows, both in forests and ornamental plant nurseries, were conducted in Central Europe (Poland) by Puchalska et al. (2014). The authors stated that the dominant phytoseid species in natural conditions was Euseius finlandicus (Oudemans), whereas in nurseries willows were most frequently inhabited by Typhlodromus pyri Scheuten. Both the species are considered to be important predators of phytophagous mites in European orchards and vineyards (Schruft 1985; Maixner 1990; Abdallah et al. 2001). Their positive association with spider mites occurring on cultivated willows (Puchalska et al. 2014) indicates their potential role in pest management in ornamental nurseries. Data concerning developmental and reproductive parameters of both mentioned natural enemies feeding on their potential preys may provide important information into pest management programs. These parameters, especially the intrinsic rate of increase $\left(\mathrm{r}_{\mathrm{m}}\right)$, are increasingly used as a means of selecting promising biocontrol candidates (Roy et al. 2003). Laboratory studies on development and reproduction of $T$. pyri and E. finlandicus feeding on different preys, i.e., tenuipalpids, eriophyoids, tydeids or even scale insects or whiteflies (Amano and Chant 1986; Duso and Camporese 1991; Schausberger 1998; Nomikou et al. 2001; Vargas and Cardemil 2005; Lorenzon et al. 2012) were previously conducted revealing information on predator-prey 
relationships. Several investigations were performed to determine life parameters of these predators fed on tetranychids such as Panonychus ulmi (Koch), Eotetranychus tiliarium (Hermann), Eotetranychus carpini (Oudemans) and Te. urticae (Zaher and Shehata 1971; Kropczyńska et al. 1988; Duso and Camporese 1991; Lorenzon et al. 2012). However, life histories of $T$. pyri and E. finlandicus reared on spider mites obtained from willows have yet to been studied. Those findings may improve knowledge useful in biological control of these key pests of ornamental nurseries. Typhlodromus pyri is classified as type III lifestyle-generalist predator and E. finlandicus as type IV-pollen feeding generalist predator (McMurtry et al. 2013). It is known that both these phytoseiids are able to successfully develop on pollen of different plant species (Duso and Camporese 1991; Schausberger 1992; Broufas and Koveos 2001; Lorenzon et al. 2012). Therefore, we decided to include in the experiments rape pollen as potential non-prey food. European Union is one of the major producers of oilseed rape (Brassica napus L.) (Carré and Pouzet 2014), with steadily increasing production area, thereby making the plant pollen easily available. Although the rape pollen is entomophilous, it can be airborne up to 1-1.5 km (Timmons et al. 1995, Devaux et al. 2005). Moreover, the pollen has a great nutritional quality for some arthropods especially due to high content of proteins and essential amino acids (Cook et al. 2003, Keller et al. 2005). A positive effect of rape pollen on E. finlandicus and/or T. pyri development could indicate its ability for rearing of the phytoseiids.

The aims of the present study were (1) to determine whether T. pyri and E. finlandicus can develop and reach maturity fed on spider mites occurring on willows, i.e., S. schizopus, $S$. garmani and Te. urticae, and (2) to assess effects of different diets (the three spider mites species and rape pollen) on the predators' development, reproduction and demographic parameters.

\section{Materials and methods}

\section{Plant material}

Three-year old (counting from grafting) and $1.2 \mathrm{~m}$ high trees of goat willow (Salix caprea) cv. Kilmarnock were grown in plastic pots $(30 \mathrm{~cm}$ diameter, $40 \mathrm{~cm}$ deep) filled with garden soil. Plants were watered on alternate days. Willows were divided to four groups kept in separate walk-in plant growth rooms $\left(25 \pm 5{ }^{\circ} \mathrm{C}, 65 \pm 10 \% \mathrm{RH}\right.$ and 16L:8D photoperiod). One of the rooms contained only uninfested plants. On trees kept in the remaining three rooms, three different spider mite species were cultured separately. Four willows were placed in each plant growth room, close to each other to allow spider mites to move freely between plants.

\section{Phytophagous mites rearing}

Schizotetranychus schizopus was obtained from S. caprea cv. Kilmarnock leaves, and Te. urticae from $S$. caprea cv. Pendula leaves from ornamental plant nurseries situated in central Poland. A stock colony of $S$. garmani was established with individuals collected from S. caprea, grown in Powsin forest, in central Poland. About 60 females of each spider mite species were placed separately in modified Munger cells (as described below) for oviposition. After laying eggs, females were slide-mounted in Heinze PVA medium for phase contrast microscopic examination (Walter and Krantz 2009). The progeny of each 
spider mite species was then reared on detached willow leaves (Kilmarnock) placed upside-down directly on a wet sponge in open plastic trays containing water. Mites were reared for two generations in environmental chambers (Sanyo MLR-350) at $25 \pm 0.5^{\circ} \mathrm{C}$, $70 \pm 10 \% \mathrm{RH}$ and 16L:8D photoperiod. Then leaves with the respective spider mite species were transferred on willow trees placed in plant growth rooms (each species to a separate room). Every 3 weeks one uninfested tree was added to each room to maintain the culture.

\section{Stock colony of Euseius finlandicus and Typhlodromus (T.) pyri}

Euseius finlandicus was collected from S. caprea trees growing in Łomianki forest in central Poland. The stock colony of $T$. pyri was initiated with specimens obtained from the Research Institute of Pomology and Floriculture in Skierniewice, Poland, where the mites were reared under laboratory conditions $\left(24 \pm 2{ }^{\circ} \mathrm{C}, 70 \pm 10 \% \mathrm{RH}\right.$ and $16 \mathrm{~L}: 8 \mathrm{D}$ photoperiod) on Phaseolus vulgaris L. plants infested by Te. urticae. Detached common bean plants bearing mites were transferred in refrigeration container to the Warsaw University of Life Sciences-SGGW (Warsaw, Poland).

Separate stock colonies of E. finlandicus and T. pyri were then maintained in the laboratory of the Department of Applied Entomology (SGGW) in the environmental test chambers $\left(25 \pm 5{ }^{\circ} \mathrm{C}, 70 \pm 10 \% \mathrm{RH}\right.$ and $16 \mathrm{~L}: 8 \mathrm{D}$ photoperiod $)$. Using a fine paint brush, the predators were placed on detached willow leaves (Kilmarnock) lying on four layers of filter paper, which rested on a wet sponge $13 \times 13 \mathrm{~cm}$ in an open plastic box $(14 \times 17 \times 6.5 \mathrm{~cm})$. To keep the sponge wet and to prevent the mites from escaping, water was added to the boxes. Additionally strips of wet tissue paper were placed on leaves to provide water. Rape pollen (Brassica napus L.) or all stages of Te. urticae or $S$. schizopus or $S$. garmani, obtained from the cultures described above, were provided to the predators as food. The pollen of B. napus plants grown in an ecological apiary (Lower Silesia Province, Poland) was collected in June. Bottom pollen traps (Dadant, USA) were used for receiving pollen pellets from legs of honey bees. Then the pollen was dried and stored in a freezer $\left(-18{ }^{\circ} \mathrm{C}\right)$. For the experiments it was thawed and kept in a refrigerator at $4{ }^{\circ} \mathrm{C}$ for maximum 1 week. Mites were reared at these conditions for at least four generations before conducting the experiment.

\section{Experimental rearing units}

All experiments were performed in environmental chambers (Sanyo MLR-350) at $25 \pm 0.5{ }^{\circ} \mathrm{C}, 70 \pm 10 \% \mathrm{RH}$ and $16 \mathrm{~L}: 8 \mathrm{D}$ photoperiod. We applied the method of individual rearing of phytoseiid mites on non-infested and fully expanded detached leaves of $S$. caprea 'Kilmarnock'. The experimental unit was a modified Munger cell (Overmeer 1985). The cell consisted of a stack of four $100 \times 50 \mathrm{~mm}$ layers, in the following order: $2 \mathrm{~mm}$ thick bottom Plexiglas plate covered with tissue paper, a detached willow leaf placed upside-down on the tissue paper, $7 \mathrm{~mm}$ thick plate with a $30 \mathrm{~mm}$ hole in the center sealed with plasticine and $2 \mathrm{~mm}$ thick top plate with a $10 \mathrm{~mm}$ ventilation hole, covered with muslin mesh. The plasticine was used to prevent mites from escaping from the arena. The stack was held together with rubber bands. To maintain humidity in the cell, the tissue paper was moistened daily with distilled water. In each unit, the predators were provided with surplus amounts of the following food items: (1) larvae and protonymphs of $T e$. urtice, (2) larvae and protonymphs of S. schizopus, (3) larvae and protonymphs of $S$. garmani or (4) rape pollen. Preys were refreshed twice a day with larval stages of 
tetranychids. Pollen was replenished every day with a fine paint brush, about $0.5 \mathrm{mg}$ per day. A piece of a transparent plastic sheet folded in the shape of a tent was placed over each arena as a shelter and oviposition site for phytoseiids. Once every 9 days E. finlandicus and $T$. pyri individuals were transferred to a new experimental units with the appropriate prey, as previously described, to avoid an effect of leaf aging.

\section{Life history experiment}

Twelve hours before the experiment gravid females of both phytoseiid species were transferred from a stock colonies to separate rearing units to obtain eggs of similar age. After that time eggs were placed individually in the Munger cells described above. Thirty replicates per combination of Phytoseiidae species and diet were used. To determine the duration and survivorship of each life stage of E. finlandicus and T. pyri, observations were made every $24 \mathrm{~h}$ until all individuals had reached adulthood. The presence of an exuvium was used to establish successful molting to the next developmental stage.

After completing the immature development, females were transferred to new experimental units with the appropriate food and paired with a male. When the male died or escaped, a new one was added from the respective stock colony. Fifteen replicates for each predator/food combination were used. The experimental units were examined every $24 \mathrm{~h}$ to determine the duration periods of pre-oviposition, oviposition, post-oviposition as well as longevity and fecundity of females. The eggs laid the same day were placed in a single unit and reared to adulthood to determine sex-ratio of the progeny.

\section{Data analysis}

Influence of phytoseiid species and food item on immature developmental time, female longevity, duration of pre-oviposition, oviposition and post-oviposition was studied by two-way analysis of variance, which also included species-by-food interaction. The fitted models were checked graphically (Quinn and Keough 2002); in all the situations the fit was sufficient. Since in all the analyses the interaction between the predator species and food source was statistically significant, multiple comparisons were conducted for combinations of these two factors, without adjustment for multiple testing (Webster 2007, Kozak 2009).

Comparison of female fecundity on different diets was done by means of generalized linear models, with Poisson distribution of the residuals. Since the variability in the data when compared to the mean of the Poisson distribution was too small, quasi generalized linear modeling was employed. For a two-way model (with predator species and food item as factors) a significant interaction was observed, so again pair-wise comparisons for combinations of the two factors was employed, without adjustment for multiple testing (Webster 2007; Kozak 2009).

Life tables were constructed from the observed age-specific survival rate $\left(l_{x}\right)$ and agespecific fecundity rate $\left(m_{x}\right)$ [net reproductive rate $\left(R_{0}\right)$, mean generation time $(T)$, intrinsic rate of population increase $\left(r_{m}\right)$ and finite rate of population increase $(\lambda)$ ] (Birch 1948). Standard errors of the population parameters, estimated for the studied phytoseiids reared on particular food items, and pair-wise comparisons of these parameters, were studied with the jackknife method (Maia et al. 2000), without adjustment for multiple testing (Webster 2007; Kozak 2009). 


\section{Results}

Food source and phytoseiid species significantly affected developmental times of $E$. finlandicus and $T$. pyri (Table 1 ). The egg stage duration of the mites significantly differed among the food items. On the other hand, on particular prey, embryonic development of $E$. finlandicus and T. pyri did not differ (2.7 and 2.4 days on Te. urticae; 2.1 and 2.2 days on S. schizopus; 2.0 and 2.2 days on $S$. garmani). Only when females of both predators were taken from stock colonies provided with rape pollen, eggs stage duration of $T$. pyri was longer than for E. finlandicus (Table 1).

The mean duration of larval stage was the highest for E. finlandicus feeding on $S$. schizopus (mean $\pm \mathrm{SE}=2.1 \pm 0.07$ days). The lowest mean duration of $E$. finlandicus larval stage was obtained on Te. urticae ( $0.9 \pm 0.06$ days). Larval duration of $T$. pyri reared on particular food items did not differ. The larval developmental period of $T$. pyri was on each tested diet similar to that observed for E. finlandicus feeding on S. schizopus (ca. 0.8 day). For $T$. pyri the non-feeding larval stage was the shortest developmental phase.

Protonymphs and deutonymphs of E. finlandicus fed on S. schizopus, S. garmani or rape pollen required a significantly shorter period ( $<2$ days) to reach the next stages than $E$. finlandicus fed on Te. urticae or T. pyri provided with all surveyed items. The highest nymphal duration (over 4 days) was observed for $T$. pyri reared on rape pollen. Overall duration of juvenile developmental time was comparable for $T$. pyri fed S. schizopus and $E$. finlandicus reared on S. schizopus, S. garmani or rape pollen (ca. 8 days). Duration of development from egg to adult was significantly longest (12.9 \pm 0.23 days) when rape pollen was offered to $T$. pyri. Immature mortality was the lowest for E. finlandicus fed on rape pollen (mean $3.7 \%$ ) and the highest for T. pyri on the same food $(30.6 \%)$ (Table 1$)$.

Two-way ANOVA showed significant interactions between diet and predator species for pre-oviposition, oviposition and post-oviposition periods (Table 2). Duration of preoviposition was shortest when E. finlandicus fed on S. garmani $(2.0 \pm 0.51$ days $)$ and the longest for $T$. pyri fed on rape pollen ( $4.4 \pm 0.19$ days). For the other tested predator-food combinations no differences in pre-oviposition period were observed (ca. 3 days). On average, females of $T$. pyri reared on $S$. garmani oviposited for $28.5 \pm 1.49$ days. Oviposition time was $3.5 \times$ shorter when the same predator was provided with rape pollen (8.1 \pm 0.35 days). Euseius finlandicus females oviposited for $19 \pm 1.54$ to $23.1 \pm 0.27$ days. Post-oviposition of E. finlandicus did not differ significantly on particular food items and took around 2 days. Typhlodromus pyri post-oviposition time on each tested food was much longer than for E. finlandicus (Table 2).

When spider mites were offered as food, females of $T$. pyri lived significantly longer than females of E. finlandicus (on average 11.9 days longer on Te. urticae, 10.5 days longer on S. schizopus, and 13.2 days longer on S. garmani) (Table 2). Provided with rape pollen, E. finlandicus females lived about 6 days longer (27.9 \pm 0.65 days) than females of $T$. pyri $(21.7 \pm 1.16$ days $)$.

Fecundity of E. finlandicus females (ranging from $12.2 \pm 0.92$ to $21.1 \pm 1.08$ eggs per female) was significantly lower than that of $T$. pyri (which ranged from $19.9 \pm 0.93$ to $29.1 \pm 0.95$ eggs per female) when predators were fed on the respective spider mite species. On rape pollen, total number of eggs laid by E. finlandicus females was about $4 \times$ higher than that laid by $T$. pyri (5.9 \pm 0.36 eggs per female). Oviposition rate (mean eggs/ female/day) was highest $(1.3 \pm 0.11)$ for $T$. pyri feeding on $S$. schizopus (Table 2). For $E$. finlandicus oviposition rate was significantly higher on rape pollen than on spider mites 


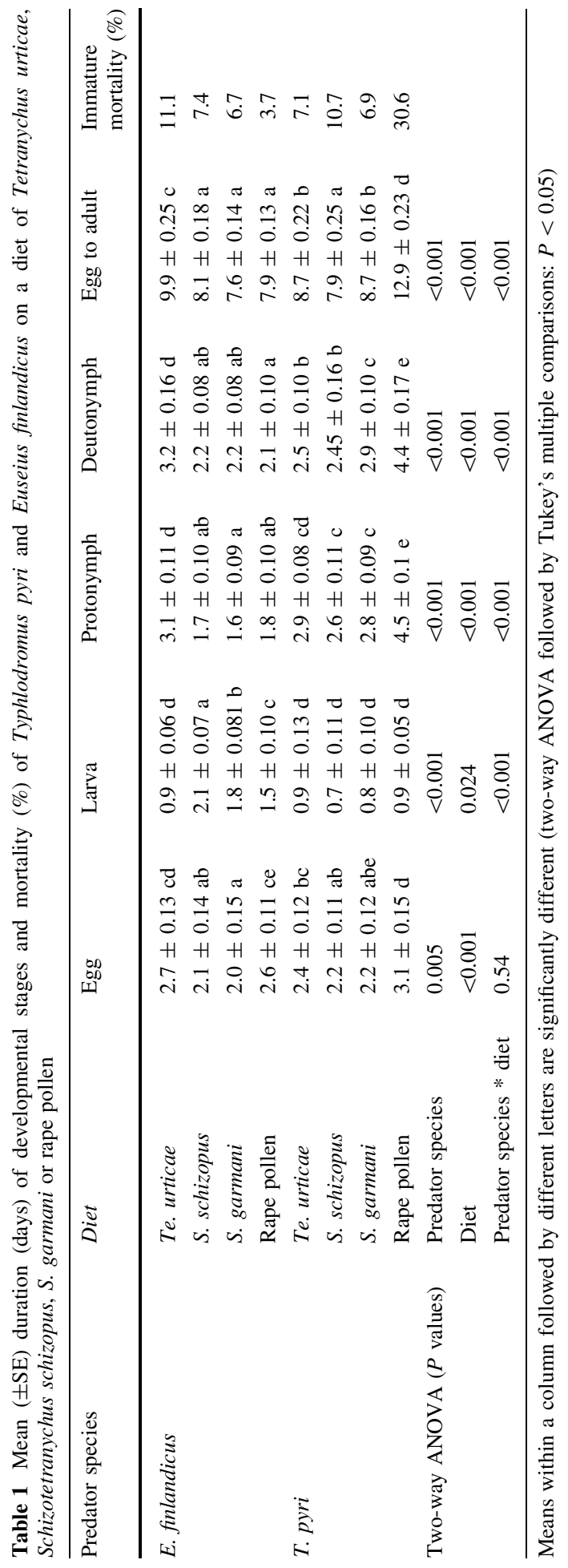




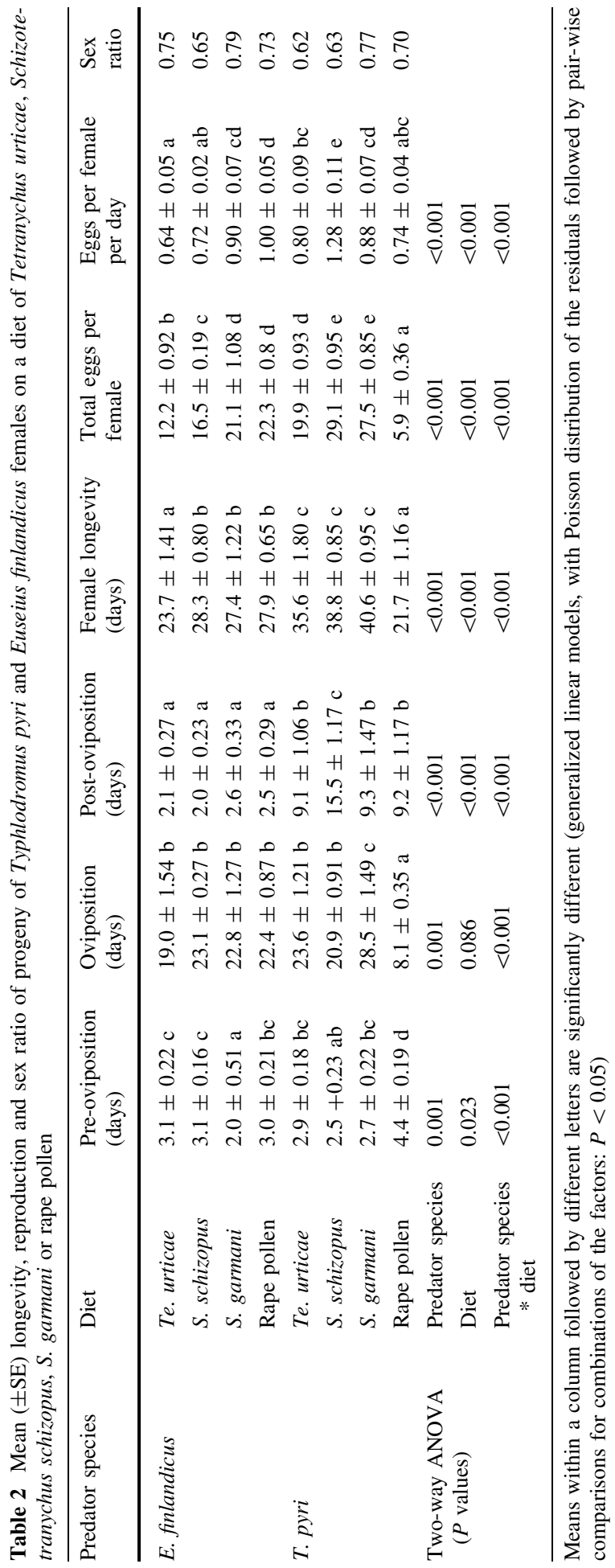


(Table 2). Offspring sex ratio did not differ significantly among surveyed predator species reared on the studied diets (Table 2).

Fed on particular spider mite species, $T$. pyri showed higher net reproductive rate $\left(R_{0}\right)$ than E. finlandicus (Table 3). On the other hand, when predators were fed on rape pollen, $R_{O}$ value for $E$. finlandicus $(15.7 \pm 0.56)$ was over $5 \times$ greater than that for $T$. pyri $(2.9 \pm 0.18)$. Mean generation time $(T)$ was shortest for $T$. pyri reared on $S$. garmani $(20.8 \pm 0.45)$ and E. finlandicus fed on S. schizopus $(20 \pm 0.2)$. The longest mean generation time was observed for $T$. pyri provided with $S$. garmani $(25.5 \pm 0.71)$. The intrinsic rate of population increase $\left(r_{m}\right)$ and finite rate of population increase $(\lambda)$ were highest when E. finlandicus was fed on $S$. garmani $\left(r_{m}=0.132, \lambda=1.14\right)$ or $T$. pyri was fed on $S$. schizopus $\left(r_{m}=0.136, \lambda=1.15\right)$. The lowest $r_{m}$ and $\lambda$ were observed for $T$. pyri fed on rape pollen $\left(r_{m}=0.05, \lambda=1.05\right)$, whereas the parameters established for $E$. finlandicus fed on pollen were significantly higher than on Te. urticae or S. schizopus (Table 3).

\section{Discussion}

Both T. pyri and E. finlandicus developed from egg to adulthood feeding on preys such as Te. urticae, S. schizopus and S. garmani originating from willows. However, the diet affected both biological and demographic parameters of the predators. Only the duration of larval stage of $T$. pyri was similar on the different diets. It seems reasonable because larvae of $T$. pyri usually molt to protonymphs without feeding (Schausberger 1999). Development of the other $T$. pyri and $E$. finlandicus immature stages, interestingly including eggs, was affected by the diet. Differences in egg-stage duration of females provided with different foods could indicate the influence of the maternal diet on eggs development. Such a phenomenon was also reported by Zemek (1993) and Hoffmann et al. (2011).

While feeding on S. schizopus - the most common spider mite species occurring on willows (Puchalska et al. 2014) - both tested predators reached adulthood in an equally short time. When $S$. garmani was provided as a food, E. finlandicus developed significantly faster than $T$. pyri. The opposite situation was observed during predators' feeding on juvenile stages of Te. urticae. Tetranychus urticae was offered as food for T. pyri and E.

Table 3 Mean $( \pm \mathrm{SE})$ life table parameters of Typhlodromus pyri and Euseius finlandicus females on a diet of Tetranychus urticae, Schizotetranychus schizopus, S. garmani and rape pollen

\begin{tabular}{llrlll}
\hline Predator species & Diet & \multicolumn{1}{c}{$R_{0}$} & \multicolumn{1}{l}{$\mathrm{T}$} & \multicolumn{1}{l}{$\mathrm{r}_{\mathrm{m}}$} & \multicolumn{1}{l}{$\lambda$} \\
\hline E. finlandicus & Te. urticae & $8.1 \pm 0.61 \mathrm{~b}$ & $23.1 \pm 0.74 \mathrm{c}$ & $0.090 \pm 0.0022 \mathrm{~b}$ & $1.09 \pm 0.0024 \mathrm{~b}$ \\
& S. schizopus & $10.0 \pm 0.37 \mathrm{c}$ & $22.0 \pm 0.45 \mathrm{bc}$ & $0.105 \pm 0.0013 \mathrm{c}$ & $1.11 \pm 0.0015 \mathrm{c}$ \\
& S. garmani & $15.5 \pm 0.80 \mathrm{e}$ & $20.8 \pm 0.45 \mathrm{ab}$ & $0.132 \pm 0.0013 \mathrm{f}$ & $1.14 \pm 0.0015 \mathrm{f}$ \\
& Rape pollen & $15.7 \pm 0.56 \mathrm{e}$ & $22.2 \pm 0.40 \mathrm{c}$ & $0.124 \pm 0.0016 \mathrm{e}$ & $1.13 \pm 0.0018 \mathrm{e}$ \\
T. pyri & Te. urticae & $11.5 \pm 0.55 \mathrm{~d}$ & $22.2 \pm 0.11 \mathrm{c}$ & $0.110 \pm 0.0017 \mathrm{~d}$ & $1.12 \pm 0.0019 \mathrm{~d}$ \\
& S. schizopus & $15.3 \pm 1.20 \mathrm{e}$ & $20.0 \pm 0.20 \mathrm{a}$ & $0.136 \pm 0.0037 \mathrm{f}$ & $1.15 \pm 0.0043 \mathrm{f}$ \\
& S. garmani & $19.7 \pm 0.61 \mathrm{f}$ & $25.5 \pm 0.71 \mathrm{~d}$ & $0.117 \pm 0.0030 \mathrm{~d}$ & $1.12 \pm 0.0034 \mathrm{~d}$ \\
& Rape pollen & $2.9 \pm 0.18 \mathrm{a}$ & $21.1 \pm 0.25 \mathrm{~b}$ & $0.050 \pm 0.0027 \mathrm{a}$ & $1.05 \pm 0.0028 \mathrm{a}$ \\
\hline
\end{tabular}

Means within a column followed by different letters are significantly different (Jackknife method: $P<0.05$ ) 
finlandicus also by other authors (Kropczyńska 1970; Schausberger 1992; Zhang and Croft 1994; Zemek 1993). Zhang and Croft (1994) showed that overall development time (eggadult) of $T$. pyri provided with 20 Te. urticae eggs per day took 8.73 days; thus it was comparable with that observed in our experiment when the phytoseiid fed on larvae and protonymphs of Te. urticae (8.7 days). In the study by Zemek (1993) T. pyri fed on diapausing females of Te. urticae and reached adulthood after over 19 days. So long developmental time could be explained by a limited opportunity of the sub-adult stages of T. pyri to grasp and feed on larger females of the two spotted spider mites (Zemek 1993) than on larvae and protonymps of the pest (i.e., offered in our investigations). Developmental times of $E$. finlandicus provided in our tests with juvenile stages of Te. urticae were close to those reported by Kropczyńska (1970) or Schausberger (1992). In turn, Abdallah et al. (2001) stated that overall immature stage duration of E. finlandicus feeding on larvae and protonymphs of Te. urticae was shorter than that in our study. The differences may be due to different host plants used for rearing spider mites (common bean and willows). Indeed, Koller et al. (2007) and Ferrero et al. (2014) have revealed an indirect, preymediated host-plant effect on phytoseiid performance.

Other spider mite species, i.e., E. carpini was tested as food for T. pyri by Duso and Camporese (1991). During feeding on this prey, predator development (6.3 days) was shorter than on each of tetranychid species tested by us. Still, the direct comparison of $T$. pyri life parameters obtained by Duso and Camporese (1991) and by us is difficult because of different rearing conditions during the experiments. It was previously proved that the temperature may influence developmental and reproductive parameters of Phytoseiidae (Hayes and McArdle 1987; Broufas et al. 2007; Lee and Gillespie 2011; Ganjisaffar et al. 2011; Gadino and Walton 2012).

Several studies indicated a significant role of T. pyri in controlling $P$. ulmi in vineyards or orchards (Boller et al. 1988; Maixner 1990; Duso 1992a; Camporese and Duso 1996). The importance of E. finlandicus in the control of European red mite was also previously described by Van de Vrie (1975), Sechser et al. (1984), Schausberger (1991) and Duso (1992b). Therefore, it is worth to compare life parameters of the predators fed on P. ulmi and on spider mites from willows. Euseius finlandicus overall development time on $S$. garmani was equal to that reported by Kropczynska (1970) for the predator fed on P. ulmi. Moreover, the number of eggs laid by E. finlandicus females fed on S. garmani was greater than on any other spider mite or eriophyid mite species previously tested (Chant 1959; Kropczyńska 1970; Amano and Chant 1986; Kropczyńska et al. 1988; Schausberger 1992; Abdallah et al. 2001). Nevertheless, the longevity and fecundity of T. pyri females were higher on each tested spider mite species than in the case of $E$. finlandicus fed on the same food. The fecundity of $T$. pyri females fed on S. schizopus and S. garmani was similar to that reported by Sengonca et al. (2003) for T. pyri fed on nymphs of P. ulmi (31 eggs/ overall life span of female). Similar reproductive parameters obtained by the predator on $P$. ulmi and on spider mites from willows indicate a potential role of $T$. pyri as biocontrol agent of $S$. schizopus and S. garmani. Moreover, higher (or close to) values of $r_{m}$ obtained for T. pyri fed on S. schizopus (our data) than on P. ulmi (Overmeer 1981; Lorenzon et al. 2012) encourage future studies on the predator's effectiveness in this mite's management.

Both surveyed predatory mites were able to develop also on alternative food, i.e., pollen of B. napus. The alternative food may be important for predatory mites in two ways. First, it may help the predator to maintain itself in a locality where spider mites are scarce. Second, it may be of value for rearing predators in laboratory conditions, even if it is not necessarily available to the predator under natural conditions (Overmeer 1985). Pollen can be one of the most valuable alternative food for many phytoseiid species (Addison et al. 
2000; Kasap 2005; Bermudez et al. 2010). Its high protein and oil contents make it nutritionally suitable for many arthropods that ordinarily consume prey-food (Lundgren 2009). In some circumstances the presence of pollen can reduce predation rate or search efficiency of phytoseiid mites (Wei and Walde 1997), but very often it is considered as an important factor in Phytoseiidae survival (Overmeer 1985). Our results suggest that rape pollen is suitable as an alternative food especially for E. finlandicus. Whereas developmental and demographic parameters of $T$. pyri obtained on rape pollen were much lower than on each spider mite species tested, longevity and fecundity of E. finlandicus females observed when fed on pollen was comparable with those obtained on $S$. garmani. Also demographic parameters of $E$. finlandicus indicate that, just after $S$. garmani, rape pollen had the highest nutritional value of surveyed food items. Commercially available rape pollen may be provided on plants as a complementary food. Positive effect of such conservation of indigenous phytoseiid fauna was noticed by Maoz et al. (2011). The pollen can be also used in commercial or small scale mass rearing production systems of $E$. finlandicus.

According to Slone and Croft (2001), T. pyri has high mobility and search capacity, thank to which it is able to find complementary food when its prey is scarce. Nevertheless, Kropczyńska-Linkiewicz (1973) revealed that although T. pyri was able to develop feeding on pollen, it preferred prey-food. Duso and Camporese (1991) also demonstrated the better response of $T$. pyri to spider mites than to pollen which stays with accordance to our results.

Reassuming, the ability of $T$. pyri and E. finlandicus to develop and obtain high values of reproductive and demographic parameters while feeding on S. schizopus and S. garmani (respectively) suggests their potential role in spider mite control on ornamental willows. Moreover, the capability of $T$. pyri of building up resistance to pesticides, even to those compounds that cause high mortality rates such as pyrethroids or organophosphorous insecticides (Overmeer and van Zon 1983; Vidal and Kreiter 1995; Bonafos et al. 2007), gives the opportunity to use the predatory mite in integrated pest management (IPM) conduced in nurseries. Although most authors consider E. finlandicus to be quite sensitive to pesticides (Tuovinen and Rokx 1991; Zacharda 2001), it was reported as dominant in the Phytoseiidae complex in organic (Szabó et al. 2014), ecological and IPM orchards (Praslicka et al. 2009). Moreover, the advantage of E. finlandicus is the ability to develop on alternative food like pollen. It can be very important especially during spring when other food sources are unavailable. Additionally McMurtry (1992) reported that generalist phytoseiids (like $T$. pyri and E. finlandicus) are capable of building up more stable populations that are less dependent on dispersal to new sites in search of prey than specialists. Therefore, our data suggest that both surveyed predatory species, namely $T$. pyri and $E$. finlandicus, have features making them promising biocontrol agents in spider mite control on willows.

Acknowledgments We would like to thank Dr. Bartosz Kaźmierczak for his help in mass breeding of the mites, and Dr. Mariusz Lewandowski from the Department of Applied Entomology, Warsaw University of Life Sciences-SGGW, for all comments on the former versions of the manuscript. We also thank the anonymous reviewers for very deep and helpful insights on the manuscript. This study was financially supported by the Polish Ministry of Science and Higher Education [Grant Number 10007 32/0555].

Open Access This article is distributed under the terms of the Creative Commons Attribution 4.0 International License (http://creativecommons.org/licenses/by/4.0/), which permits unrestricted use, distribution, and reproduction in any medium, provided you give appropriate credit to the original author(s) and the source, provide a link to the Creative Commons license, and indicate if changes were made. 


\section{References}

Abdallah AA, Zhang ZQ, Masters GJ, McNeill S (2001) Euseius finlandicus (Acari: Phytoseiidae) as a potiential biocontrol agent against Tetranychus urticae (Acari: Tetranychidae): life history and feeding habits on three different types of food. Exp Appl Acarol 25:833-847. doi:10.1023/A:1020431531446

Addison JA, Hardman JM, Walde SJ (2000) Pollen availability for predaceous mites on apple: spatial and temporal heterogeneity. Exp Appl Acarol 24:1-18. doi:10.1023/A:1006329819059

Amano H, Chant DA (1986) Laboratory studies on the feeding habits, reproduction and development of three phytoseiid species, Typhlodromus pomi, Phytoseius macropilis and Amblyseius finlandicus (Acari: Phytoseiidae), occurring on abandoned apple trees in Ontario, Canada. Exp Appl Acarol 2(4):299-313. doi:10.1007/BF01193896

Bermudez P, Vargas R, Cardemil A, Lopez E (2010) Effect of pollen from different plant species on development of Typhlodromus pyri (Sheuten) (Acari: Phytoseiidae). Chil J Agric Res 70(3):408-416

Birch LC (1948) The intrinsic rate of natural increase of an insect population. J Anim Ecol 17:15-26

Boller EF, Renuld U, Candolfi MP (1988) Hedges as potential sources of Typhlodromus pyri, the most important predatory mite in vineyard of Northern Switzerland. Entomophaga 33(2):249-255. doi:10. 1007/BF02372661

Bonafos R, Serrano E, Auger P, Kreiter S (2007) Resistance to deltamethrin, lambda-cyhalothrin and chlorpyriphos-ethyl in some populations of Typhlodromus pyri Scheuten and Amblyseius andersoni (Chant) (Acari: Phytoseiidae) from vineyards in the south-west of France. Crop Prot 26:169-172. doi:10.1016/j.cropro.2006.10.001

Broufas GD, Koveos DS (2001) Development, survival and reproduction of Euseius finlandicus (Acari: Phytoseiidae) at different constant temperatures. Exp Appl Acarol 25:441-460. doi:10.1023/A: 1011801703707

Broufas GD, Pappas ML, Koveos DS (2007) Development, survival, and reproduction of the predatory mite Kampimodromus aberrans (Acari: Phytoseiidae) at different constant temperatures. Environ Entomol 36:657-665. doi:10.1093/ee/36.4.657

Camporese P, Duso C (1996) Different colonization patterns of phytophagous and predatory mites (Acari: Tetranychidae, Phytoseiidae) on three grape varieties: a case study. Exp Appl Acarol 20:1-22. doi:10. 1007/BF00051473

Carré P, Pouzet A (2014) Rapeseed market, worldwide and in Europe. Oilseeds Fats Crops Lipids 21(1):D102. doi:10.1051/ocl/2013054

Chant DA (1959) Phytoseiid mites (Acarina: Phytoseiidae)—part I: bionomics of seven species in Southeastern England. Part II: a taxonomic review of the family Phytoseiidae, with description of 38 new species. Can Entomol 91(12):1-166

Cook J, Beyea J (2000) Bioenergy in the United States: progress and possibilities. Biomass Bioenergy 18:441-455. doi:10.1016/S0961-9534(00)00011-8

Cook SM, Awmack CS, Murray DA, Williams IH (2003) Are honey bees' foraging preferences affected by pollen amino acid composition? Ecol Entomol 28:622-627. doi:10.1046/j.1365-2311.2003.00548.x

Cranham JE, Helle W (1985) Pesticide resistance in Tetranychidae. In: Helle W, Sabelis MW (eds) Spider mites, their biology, natural enemies and control, vol 1B. Elsevier, Amsterdam, p 458

Devaux C, Lavigne C, Falentin-Guyomarc'h H, Vautrin S, Lecomte J, Klein EK (2005) High diversity of oilseed rape pollen clouds over an agro-ecosystem indicates long-distance dispersal. Mol Ecol 14(8):2269-2280. doi:10.1111/j.1365-294X.2005.02554.X

Duso D (1992a) Biological control of the Tetranychid mites in peach orchards of northern Italy: role of Amblyseius andersoni (Chant) and Amblyseius finlandicus (Oud.) (Acari: Phytoseiidae). Acta Phytophathol Entomol Hung 27:211-217

Duso C (1992b) Role of Amblyseius aberrans (Oud.), Typhlodromus pyri Scheuten and Amblyseius andersoni (Chant) (Acari, Phytoseiidae) in vineyards. J Appl Entomol 114(1-5):455-462. doi:10.1111/ j.1439-0418.1992.tb01151.x

Duso C, Camporese P (1991) Developmental times and oviposition rates of predatory mites Typhlodromus pyri and Amblyseius andersoni (Acari: Phytoseiidae) reared on different foods. Exp Appl Acarol 13:117-128. doi:10.1007/BF01193662

Ferrero M, Tixier MS, Kreiter S (2014) Different feeding behaviors in a single predatory mite species-1: comparative life histories of three populations of Phytoseiulus longipes (Acari: Phytoseiidae) depending on prey species and plant substrate. Exp Appl Acarol 62:313-324. doi:10.1007/s10493-0139745-Z

Gadino AN, Walton VM (2012) Temperature-related development and population parameters for Typhlodromus pyri (Acari: Phytoseiidae) found in Oregon vineyards. Exp Appl Acarol 58:1-10. doi:10.1007/ s10493-012-9562-9 
Ganjisaffar F, Fathipour Y, Kamali K (2011) Temperature-dependent development and life table parameters of Typhlodromus bagdasarjani (Phytoseiidae) fed on two-spotted spider mite. Exp Appl Acarol 55:259-272. doi:10.1007/s10493-011-9467-z

Gigler J, Meerdink G, Hendrix EM (1999) Willow supply strategies to energy plants. Biomass Bioenergy 17:185-198. doi:10.1016/S0961-9534(99)00041-0

Gurr G, Wratten S (2000) Biological control: measures of success. Springer Science+Business Media, Dordrecht

Hayes AJ, McArdle BH (1987) A laboratory study on the predatory mite Typhlodromus pyri (Acarina: Phytoseiidae) - I: the effect of temperature and food consumption on the rate of development of the eggs and immature stages. Res Popul Ecol 29:23-83. doi:10.1007/BF02515426

Hoffmann D, Vierheilig H, Schausberger P (2011) Mycorrhiza-induced trophic cascade enhances fitness and population growth of an acarine predator. Oecologia 166(1):141-149. doi:10.1007/s00442-010-1821-z

Johansson J, Lundqvist U (1999) Estimating Swedish biomass energy supply. Biomass Bioenergy 17:85-93. doi:10.1016/S0961-9534(99)00034-3

Kasap I (2005) Life-history traits of predaceous mites Kampimodromus aberrans (Oudemans) (Acarina:Phytoseiidae) on four different types of food. Biol Control 35:40-45. doi:10.1016/j. biocontrol.2005.05.014

Kaźmierczak B (2004) Effectiveness of Kampimodromus aberrans (Oudemans) (Acari: Phytoseiidae) introduced on large-leaved linden trees to control linden spider mite population in urban environment. In: Weigmann G, Alberti G, Wohltmann A, Ragusa S (eds) Acarine biodiversity in the natural and human sphere. Proceedings of the 5th Symp EURAAC Berlin, Phytophaga, vol XIV. pp 577-584

Keller I, Fluri P, Imdorf A (2005) Pollen nutrition and colony development in honey bees: part 1. Bee World 86(1):3-10. doi:10.1080/0005772X.2005.11099641

Koller M, Knapp M, Schausberger P (2007) Direct and indirect adverse effects of tomato on the predatory mite Neoseiulus californicus feeding on the spider mite Tetranychus evansi. Entomol Exp App 125:297-305. doi:10.1111/j.1570-7458.2007.00625.x

Kozak M (2009) Analyzing one-way experiments: a piece of cake or a pain in the neck? Sci Agric 66:556-562

Kropczyńska D (1970) The biology and ecology of predatory mite Typhlodromus finlandicus (Oud.) (Acarina: Phytoseiidae) [org title: Biologia i ekologia drapieżnego roztocza Typhlodromus finlandicus (Oud.) (Acarina: Phytoseiidae)]. Zeszyty Problemowe Postępów Nauk Rolniczych 109:11-39

Kropczyńska D, Van De Vrie M, Tomczyk A (1988) Bionomics of Eotetranychus tiliarium and its phytoseiid predators. Exp Appl Acarol 5:65-81. doi:10.1007/BF02053818

Kropczyńska-Linkiewicz D (1973) The biology and effectiveness of phytoseiid predatory mites occurring in orchards [Badania nad biologią i efektywnością drapieżnych roztoczy z rodziny Phytoseiidae występujących w sadach]. Zeszyty Problemowe Postępów Nauk Rolniczych 144:59-65

Lee H, Gillespie DR (2011) Life tables and development of Amblyseius swirskii (Acari: Phytoseiidae) at different temperatures. Exp Appl Acarol 53:17-27. doi:10.1007/s10493-010-9385-5

Lockwood JA, Howarth FG, Purcell MF (2001) Balancing nature: assessing the impact of importing nonnative biological control agents (an international perspective). Entomological Society of America, Lantham

Lorenzon M, Pozzebon A, Duso C (2012) Effect of potential food sources on biological and demographic parameters of the predatory mites Kampimodromus aberrans, Typhlodromus pyri and Amblyseius andersoni. Exp Appl Acarol 58:259-278. doi:10.1007/s10493-012-9580-7

Lundgren JG (2009) Relationships of natural enemies and non-prey foods. Prog Biol Control 7:127-139. ISBN 978-1-4020-9234-3

Maia AHN, Luiz AJB, Campanhola C (2000) Statistical inference on associated fertility life table parameters using Jackknife technique: computational aspects. J Econ Entomol 93:511-518. doi:10.1603/ 0022-0493-93.2.511

Maixner M (1990) Untersuchungen zur Insektizidresistenz der Raubmilbe Typhlodromus pyri Scheuten (Acari: Phytoseiidae) an Reben des Weinbaugebiets Mosel-Saar-Ruwer-Mitt Biol Bund Land-Forstwirt 257:1-118

Maoz Y, Gal S, Argov Y, Coll M, Palevsky E (2011) Biocontrol of persea mite, Oligonychus perseae, with an exotic spider mite predator and an indigenous pollen feeder. Biol Control 59:147-157. doi:10.1016/ j.biocontrol.2011.07.014

McMurtry JA (1992) Dynamics and potential impact of 'generalist' phytoseiids in agroecosystems and possibilities for establishment of exotic species. Exp Appl Acarol 14:371-382. doi:10.1007/ BF01200574

McMurtry JA, Croft BA (1997) Life-styles of Phytoseiid mites and their roles in biological control. Annu Rev Entomol 42:291-321. doi:10.1146/annurev.ento.42.1.291 
McMurtry JA, De Moraes GJ, Sourassou NF (2013) Revision of the lifestyles of phytoseiid mites (Acari: Phytoseiidae) and implications for biological control strategies. Syst Appl Acarol 18(4):297-320. doi:10.11158/saa.18.4.1

Naher L, Haque M (2007) Biological control of Tetranychus urticae (Acari: Tetranychidae) using Phytoseiullus persimilis (Acari: Phytoseiidae). Res J Agric Biol Sci 3(6):550-553

Nomikou M, Janssen A, Schraag R, Sabelis MW (2001) Phytoseiid predators as potential biological control agents for Bemisia tabaci. Exp Appl Acarol 25:271-291. doi:10.1023/A:1017976725685

Oliveira H, Fadini MA, Venzon M, Rezende D, Rezende F, Pallini A (2009) Evaluation of the predatory mite Phytoseiulus macropilis (Acari: Phytoseiidae) as a biological control agent of the two-spotted spider mite on strawberry plants under greenhouse conditions. Exp Appl Acarol 47(4):275-283. doi:10. 1007/s10493-008-9217-z

Overmeer WPJ (1981) Notes on breeding phytoseiid mites from orchards in the laboratory. Meded Fac Landbouwwet Rijksuniv Gent 46:503-509

Overmeer WPJ (1985) Alternative prey and other food resources. In: Helle W, Sabelis MW (eds) Spiders mites their biology, natural enemies and control, vol IB. Elselvier, Amsterdam, pp 131-137

Overmeer WPJ, van Zon AQ (1983) Resistance to parathion in the predacious mite Typhlodrornus pyri Scheuten (Acarina: Phytoseiidae). Mededelingen Faculteit Landbouwwetenschappen Rijksuniversiteit Gent 43:247-251

Praslicka J, Baretkova A, Schilaramannova J, Malina R (2009) Predatory mites of the Phytoseiidae family in integrated and ecological pest management systems in orchards in Slovakia. Biologia 64:959-961. doi:10.2478/s11756-009-0163-y

Pratt PD, Rosetta R, Croft BA (2002) Plant-related factors influence the effectiveness of Neoseiulus fallacis (Acari: Phytoseiidae), a biological control agent of spider mites on landscape ornamental plants. J Econ Entomol 95(6):1135-1141. doi:10.1603/0022-0493-95.6.1135

Puchalska EK, Kropczyńska-Linkiewicz D, Kaźmierczak B (2014) Evaluation of the co-occurrence of spider mites (Acari: Tetranychidae) and phytoseiid mites (Acari: Phytoseiidae) on willows (Salix spp.) in nurseries and natural environments. Int J Acarol 40(7):473-484. doi:10.1080/01647954.2014. 956670

Quinn GP, Keough MJ (2002) Experimental design and data analysis for biologists. Cambridge University Press, Cambridge

Roy M, Brodeur J, Cloutier C (2003) Effect of temperature on intrinsic rates of natural increase (rm) of a coccinellid and its spider mite prey. Biocontrol 48:57-72. doi:10.1023/A:1021289832664

Schausberger P (1991) Vergleichende Untersuchungen zum Lebensverlauf, die Erstellung von Lebenstafeln und die Vermehrungskapazität von Amblyseius aberrans Oud. Und finlandicus Oud. (Acari: Phytoseiidae). Pflanzenschutzber 52:53-71

Schausberger P (1992) Vergleichende Untersuchungen uber den Einfluß unterschiedlicher Nahrung auf die Praimaginalentwicklung und die Reproduktion von Amblyseius aberrans Oud. und Amblyseius finlandicus Oud. (Acarina, Phytoseiidae). J Appl Entomol 113:476-486. doi:10.1111/j.1439-0418.1992. tb00692.x

Schausberger P (1999) Predation preference of Typhlodromus pyri and Kampimodromus aberrans (Acari: Phytoseiidae) when offered con- and heterospecific immature life stages. Exp Appl Acarol 23:389-398. doi:10.1023/A:1006172320540

Schruft G (1985) Grape. In: Helle W, Sabelis MW (eds) Spider mites: their biology, natural enemies and control: 1B. Elsevier, Amsterdam, pp 359-365

Sean ST, Labrecque M (2006) Use of short-rotation coppice willow clones of Salix viminalis as furnish in panel production. For Prod J 56(9):47-52. ISSN 0015-7473

Sechser B, Thueler P, Bachmann A (1984) Observations on population levels of the European red mite (Acari: Tetranychidae) and associated arthropod predatory complexes in different spray programmes over a 5-year period. Environ Entomol 13:1577-1582. doi:10.1093/ee/13.6.1577

Sengonca C, Khan IA, Blaeser P (2003) Prey consumption during development as well as longevity and reproduction of Typhlodromus pyri Scheuten (Acari, Phytoseiidae) at higher temperatures in the laboratory: Anzeiger für Schädlingskunde. J Pest Sci 76:57-64. doi:10.1046/j.1439-0280.2003.03016.x

Shrewsbury PM, Hardin MR (2003) Evaluation of predatory mite (Acari: Phytoseiidae) releases to suppress spruce spider mites, Oligonychus ununguis (Acari: Tetranychidae), on juniper. J Econ Entomol 96(6):1675-1684. doi:10.1093/jee/96.6.1675

Slone DH, Croft BA (2001) Species associations among predacious and phytophagous apple mites (Acari: Eriophydae, Phytoseidae, Stigmaeidae, Tetranychidae). Exp Appl Acarol 25:109-126. doi:10.1023/A: 1010640631355

Soika G, Łabanowski G (2003) Spider mites (Tetranychidae) recorded on ornamental trees and shrubs in nurseries. J Plant Prot Res 43(2):105-112. ISSN 1427-4345 
Szabó Á, Pénzes B, Sipos P, Hegyi T, Hajdú Z, Markó V (2014) Pest management systems affect composition but not abundance of phytoseiid mites (Acari: Phytoseiidae) in apple orchards. Exp Appl Acarol 62:525-537. doi:10.1007/s10493-013-9752-0

Timmons AM, O'Brajen ET, Charters YM, Dubbels SJ, Wilkinson MJ (1995) Assessing the risks of wind pollination from fields of genetically modified Brassica napus spp. oleifera. Euphytica 85:417-423

Tomczyk A (2004) Diseases and pests of cultivated willows. In: Grzybek A (ed) Willow: cultivation and processing technologies [Choroby i szkodniki upraw wierzbowych. Wierzba energetyczna: uprawa i technologie przetwarzania]. Wyższa Szkoła Ekonomii i Administracji w Bytomiu. ISBN 83-88587-71-4

Tuovinen T, Rokx JAH (1991) Phytoseiid mites (Acari: Phytoseiidae) on apple trees and in surrounding vegetation in southern Finland: densities and species composition. Exp Appl Acarol 12:35-46. doi:10. 1007/BF01204398

Van de Vrie M (1975) Some studies on the predator-prey relationship in Amblyseius (T.) potentillae Garmans, A. finlandicus Oud. and Panonychus ulmi (Koch) on apple. Parasitica 31:43-44

Van Leeuwen T, Vontas J, Tsagkarakou A, Tirry L (2009) Mechanisms of acaricide resistance in the twospotted spider mite Tetranychus urticae. In: Ishaaya I, Horowitz AR (eds) Biorational control of arthropod pests. Springer Science+Business Media, Dordrecht, pp 347-393. doi:10.1007/978-90-4812316-2_14

van Lenteren JC, Babendreier D, Bigler F, Burgio G, Hokkanen HMT et al (2003) Environmental risk assessment of exotic natural enemies used in inundative biological control. Biocontrol 48:3-38. doi:10. 1023/A: 1021262931608

Vargas RNO, Cardemil YA (2005) Desarrollo postembrionario y parámetros de tablas de vida de Typhlodromus pyri Scheuten, Cyndodromus californicus (McGregor) (Acarina: Phytoseiidae)y Brevipalpus chilensis (Acarina: Tenuipalpidae). Agricultura Técnica (Chile) 35:147-156. ISSN 0365-2807

Vidal C, Kreiter S (1995) Resistance to a range of insecticides in the predaceous mite Typhlodromus pyri (Acari: Phytoseiidae): inheritance and physiological mechanisms. J Econ Entomol 88:1097-1105. doi:10.1093/jee/88.5.1097

Wajnberg E, Scott JK, Quimby PC (2007) Evaluating indirect ecological effects of biological control. CABI Publishing, UK. ISBN 13: 978-0851994536

Waliszewska B, Szentner K, Spek-Dźwigała A (2011) Basic chemical composition of selected species of bush willows. Ann WULS-SGGW, For Wood Technol 76:160-163. ISSN 1898-5912

Walter DE, Krantz GW (2009) Collecting, rearing, and preparing specimens. In: Krantz GW, Walter DE (eds). A manual of Acarology. Texas Tech University Press, pp 83-96. ISBN 13: 978-0896726208

Warmbier K, Wilczy A, Danecki L (2010) Particle size dependent properties of three-layer particleboards with the core layer made from willow (Salix viminalis). Ann WULS-SGGW, For Wood Technol 72:405-409. ISSN 1898-5912

Webster R (2007) Analysis of variance, inference, multiple comparisons and sampling effects in soil research. Eur J Soil Sci 58:74-82. doi:10.1111/j.1365-2389.2006.00801.x

Zacharda M (2001) Predatory phytoseiid mites (Acari: Phytoseiidae) as bioindicators of stress impact on a farmland and buttresses of the farmland revival. Ekologia 20:47-56

Zaher MA, Shehata KK (1971) Biological studies on the predator mite Typhlodromus pyri Sch. (Acarina:Phytoseiidae) with the effect of prey and non prey substances. Z Angew Entomol 64:389-394. doi:10.1111/j.1439-0418.1971.tb02137.x

Zemek R (1993) Characteristic of developmnet and reproduction in Typhlodromus pyri na Tetranychus urticae and Cecidophyopsis ribis II: progeny of overwinter females. Exp Appl Acarol 17:847-858. doi:10.1007/BF00225858

Zhang ZQ, Croft BA (1994) A comparative life history study of immature Amblyseius fallacis, Amblyseius andersoni, Typhlodromus occidentalis and Typhlodromus pyri (Acari: Phytoseiidae) with a review of larval feeding patterns in the family. Exp Appl Acarol 18:631-657. doi:10.1007/BF00051532 